\title{
ASSESSMENT OF THE IMPACT OF URBANISATION ON AGRICULTURAL AND FOREST AREAS IN THE COASTAL ZONE OF MOSTAGANEM (WESTERN ALGERIA)
}

\author{
ABBASSIA MOSTARI $\otimes^{1}$, KHELOUFI BENABDELI² ${ }^{2}$ TAHAR FERAH ${ }^{2}$ \\ ${ }^{1}$ Department of Biology, Faculty of Life Sciences, University Abdelhamid Ibn Badis of Mostaganem, Rue Benkada Tayeb, Mostaganem 27000, Algeria; e- mail: \\ mostari_abie27@yahoo.fr,ferahtahar@yahoo.fr \\ ${ }^{2}$ Laboratary Geo-Environment and spaces development, Faculty of Sciences of Nature and Life, University Mustapha Stambouli of Mascara, BP 305 Sidi Said \\ Mascara 29000 Algeria; e-mail: kbenabdeli@yahoo.fr
}

$\bowtie$ Corresponding author

Received: 25 September 2020 / Accepted: 5 January 2021

\begin{abstract}
Mostari A., Benabdeli K., Ferah T.: Assessment of the impact of urbanisation on agricultural and forest areas in the coastal zone of Mostaganem (western Algeria). Ekológia (Bratislava), Vol. 40, No. 3, p. 230-239, 2021.

The accelerated and uncontrolled urbanisation in the coastal zone of Mostaganem is exclusively at the expense of agricultural and natural areas and is reflected in the aggravation of their degradation. The study area is a $62-\mathrm{km}$-long littoral to the west of Mostaganem and includes 11 municipalities. The Corine Land Cover nomenclature was used by exploiting data from Landsat satellite images over a 30-year period. The exploitation of statistics related to agricultural and forestry areas reveals a worrying dynamics. All spaces are under pressure mainly due to urbanisation. The phenomena of urbanization and coastalisation and the development of seaside tourism have increased the pressures on natural heritage to the point of compromising it. The analysis identified seven thematic object classes for the study area. An assessment of the dynamics of urban, forest and agricultural areas is an informative indicator of the sustainability of natural areas in the coastline of Mostaganem. The cultivated areas measured from 42,356 ha in 1985 to 38,301 ha in 2015,forest formations from 8207 ha to 9298 ha and urbanised areas from 2604 ha to 5049 ha. The dramatic land use change stimulated by rapid urbanisation in the study areas has resulted in a fundamental change in the landscape pattern. The thematic maps and the results obtained through different periods show that the predominant agricultural landscape has been gradually converted into urban areas.
\end{abstract}

Key words: coastline, dynamic, environment, land change, land cover, thematic maps.

\section{Introduction}

In recent years, the temporal dimension of landscapes has to be considered as important as the spatial dimension, in order to monitor and assess human and ecological interactions (Hasse et al., 2003; Houet et al., 2010; Li et al., 2016). According to Paegelow et al. (2014), the exploitation of coastal areas manifests itself in new forms in contradiction with any strategy of well-balanced and sustainable development of the territory. The problem of sustainable management of the Algerian littoral, a vulnerable and overexploited environment, lies in an uncontrolled urbanisation with all its consequences (Rabehi et al., 2018, 2019a; Otmani et al., 2019).The phenomenon puts constant pressure on the natural ecosystems and agricultural land (Boudjenouia et al., 2008; Semmoud, Ladhem, 2015).This pressure is caused by urbanisation and the installation of industrial and tourist activities (Lagabrielle et al., 2007; Lestrelin et al., 2007). The coastline is a territory with many types of ecosystems, habitats and landscapes that must be preserved. Despite the promulgation of the law $n^{\circ} 02-02$ of 5 February 2002 (Journal Officiel de la République Algérienne, 2002) relating to the enhancement of the Algerian coast through sustainable coastal development, the west coast $(445 \mathrm{~km})$ which stretches from the river Ouedkiss at the Moroccan border in the west up to mount of Dahra in the east, undergoes a worrying degradation. The result is a reconversion of land use resulting in the phenomenon of silting, regression of agricultural land, large loss of plant biodiversity and reconfiguration of the coastline. As a result of the concentration of the population and industry on the coast, there has been an increased need for housing, which has led to implementation of development and urban development plans. The coastline has been officially attacked (put in danger) and all the natural ecosystems have been weakened and destroyed since the coastal urban extensions were made to the detriment of the agricultural and forest area. The phenomenon of littoralisation of the region of Mostaganem has resulted in a major change in the coastal areas dominated by the establishment of summer and secondary residences as well as real estate and tourism projects (Ghodbani, Berrahi-Midoun, 2013; Ghodbani et al., 2016).This natural and protected area is used to relieve the city of Mostaganem by developing housing projects in the agglomerations of Salamandre and

(C) The Author(s) 2021. This is an open access article distributed under the terms of the CC BY-NC-ND license.

https://content.sciendo.com/view/journals/eko/eko-overview.xml 


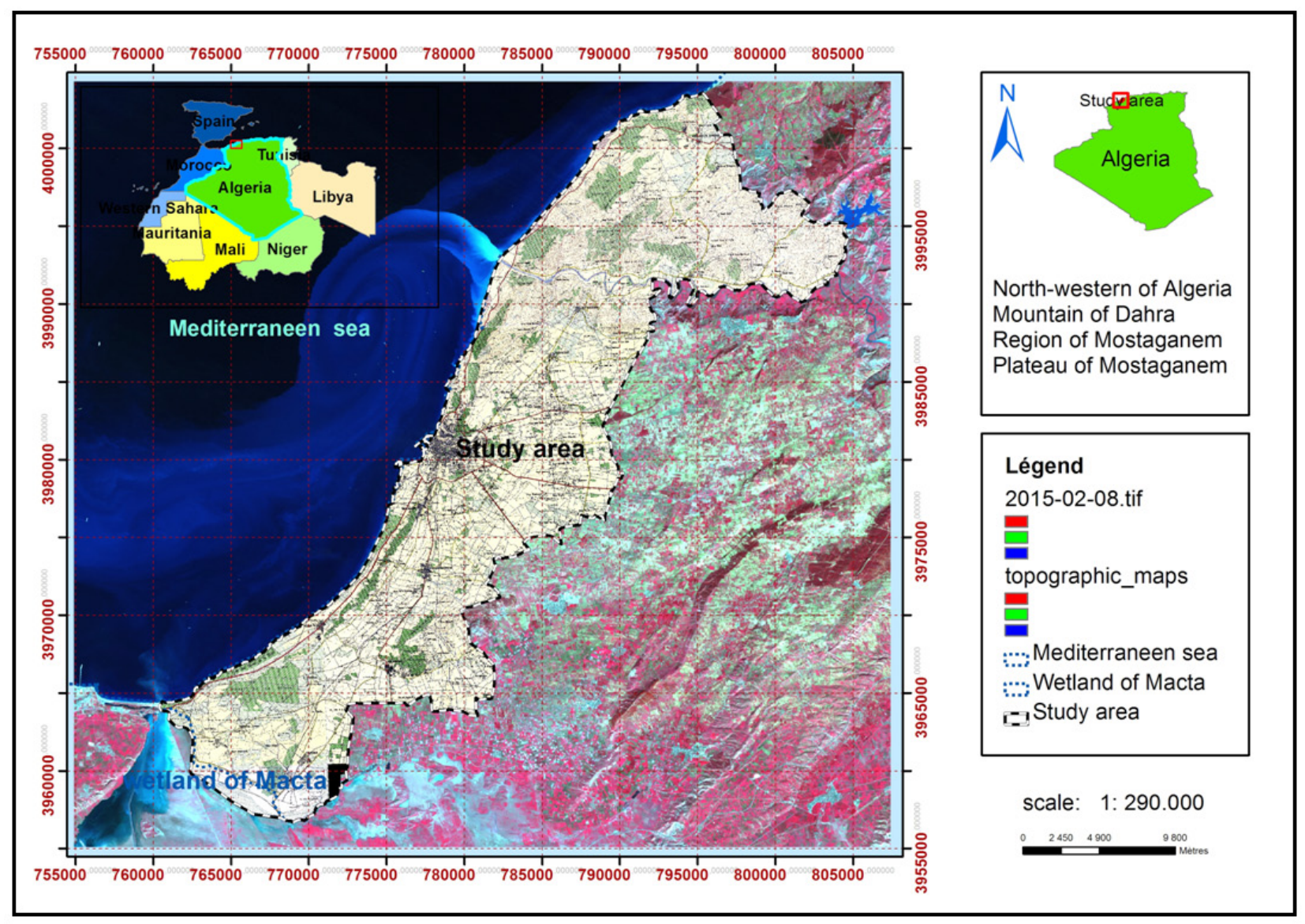

Fig. 1. Geographical location of the study area.

Kharouba (Dirassat, 2008; ANAT, 1997, 2006). All constructions are in a linear orientation facing the sea, often even at the edge of the shore, despite the legislation wich prohibits urbanisation on a strip of territory $100-\mathrm{m}$ wide from the shore and $300-\mathrm{m}$ in the event of fragility of the coastal ecosystem (Ghodbani, Semmoud, 2010). The problems caused by urbanisation are enormous and varied. Since 1970, the migration of hundreds of thousands of people from rural to urban areas has led to a strong urbanisation wich is proving multidimensional process that manifests itself through rapidly changing human population and changing land cover (Elmqvist et al., 2013). In addition to the natural factors, the anthropogenic factors also have contributed much to the situation. Human interventions like harbour, road, sandmining, tourism, beach resort and construction of stations of desalination, particularly over the last four decades, have also caused significant changes in the coastal environment (Ghodbani et al., 2015; Patra, 2017).This is the case of the littoral of Mostaganem along the coastal municipalities, where increasing conversion of agricultural and natural areas to human-dominated urban lands capes is predicted to lead to a major decline in biodiversity (Benhouhou et al., 2018). As evidenced by the scientific literature, our results demonstrate that urbanisation may fundamentally and consistently alter species composition by exerting a strong filtering effect on species dispersal characteristics (Piano et al., 2017). As demonstrated by Qiang and Lam (2015) and Aguejdad et al. (2017), the use of remote sensing in monitoring and modelling land use and cover change associated with urbanisation are of great importance in understanding how these changes interact with ecological and social processes. The use of spatial tools to illustrate explicit land changes is helpful in making land use management decisions and sustainable landscape (Gounaridis, 2016; Güngöroğlu et al., 2017; Sharma et al., 2018). The approach presented can act as a baseline to continuously monitor land change and to assist ongoing and upcoming land change mapping initiatives.

\section{Material and methods}

\section{Introducing the study area}

Located north west of Algeria, the study area is a $62-\mathrm{km}$-long littoral to the west of Mostaganem, which is $124-\mathrm{km}$ long as a whole. Its limits are: the estuary of Macta River to the west, Roumane River to the east, the Mediterranean Sea to the north and the Macta plain to the south. The surface of this area is 56,100 ha, that is, $13 \%$ of the total Mostaganem province surface. The study area is geographically located $0^{\circ} 7^{\prime} 21.60^{\prime \prime}$ west, $35^{\circ} 47^{\prime} 18.61^{\prime \prime}$ north and $0^{\circ} 23^{\prime} 1.04^{\prime \prime}$ east, $36^{\circ} 3^{\prime} 13.28^{\prime \prime}$ north. It includes 11 of $32 \mathrm{Mo}-$ staganem municipalities: Ain Nouissy, Abdelmalek Ramdane, Boudinar, Fornaka, Hassi Maméche, Kheir Eddine, Mezaghrane, Mostaganem, Sayada, Sidi Belattar and Stidia (Figs 1,2). 


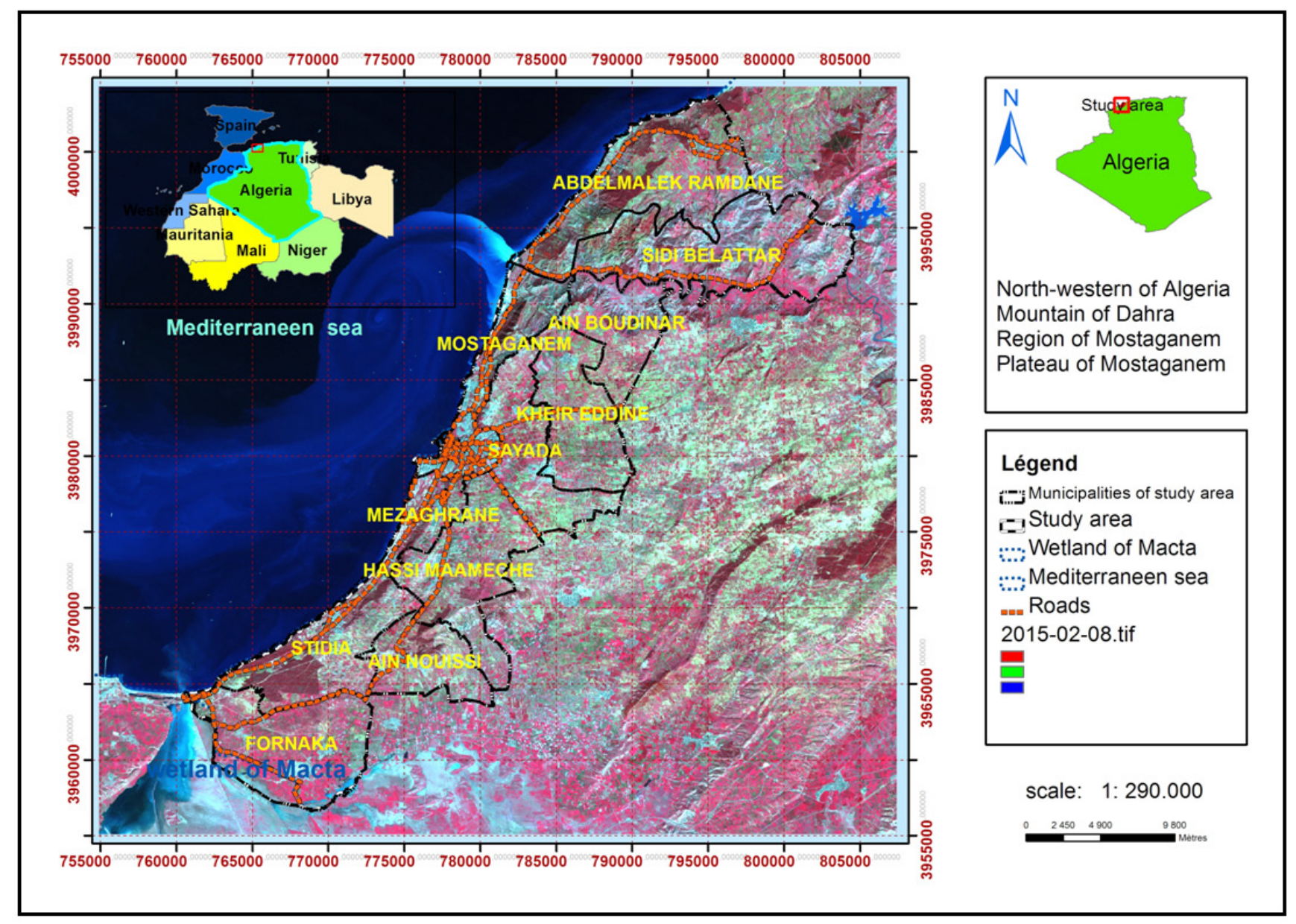

Fig. 2.Administrative situation of the study area.

Table 1. List of topographic maps used in this study.

\begin{tabular}{|l|l|l|}
\hline \multicolumn{2}{|c|}{ Topographic maps 1/50 000} \\
\hline \multirow{2}{*}{ 2-Arzew_NI_31_XXIV_2 } & 1-Sidi_Ali_NJ_31_1_7 & \multirow{2}{*}{ 4-Mostaganem_NI_31_XIX_1_East } \\
\cline { 2 - 3 } & 3-Mostaganem_NI_31_XIX_1_West & \\
\hline 5-Sig_NI_30_XXIV_4_East & 6-Mohamadia_NI_31_XIX_3_West & \\
\hline
\end{tabular}

\section{Cartography}

The exploitation of six topographic maps at 1/50,000th of 1989 (Arzew, Mostaganem, Sidi Ali, Sig and Mohammadia) made it possible to map all the studied municipalities (Table 1).

To format the map data, we used the Arc G IS 10.0 software which allowed us to georeference the maps according to UTM projection WGS 84 zone 31 datum. The georeferencing methods allowed us to stall and assemble all the maps in order to create the topographical background of the study area. To achieve maps definitively, we proceeded to the technique of mosaicing of cards, which makes it possible to assemble and merge all the maps as a single map to find the geographical situation of the zone study with its communes. To delimit the area of interest, we carried out, as part of a geographic information system (GIS), an operation of crossing layers of information. This GIS application allowed us to visualise and cut out the study area according to the size of the municipalities concerned by the area of interest by using the Comgeo digital file available in Shapefile (Shp) format. We established the Digital Terrain Model (DTM) of the area at $30-\mathrm{m}$ from Shuttle Radar Topography. The physical environment of the area is characterised by rugged terrain in the east, especially east of Mostaganem and north of the communes of Sidi Belaatar and Abdelmalek Ramdane. The altitude of the terrain varies between 0 and $415 \mathrm{~m}$. The upper altitudinal ranges (260-415 m) largely occupy the eastern part of the area, particu- 
larly those in the municipality of Sidi Belaatar. From the DTM $30-\mathrm{m}$ resolution, a slope map is established, characterised by grades of slopes that vary between 0 and $90 \%$; the $25 \%$ class dominates the study area. The south and southwest exposures dominate. The hydrographic system consists of a set of wadi, which are all oriented to the north to dump in the Mediterranean Sea. The network is classified in to six orders. Among the big wadis, mention should be made of the permanent wadi of Cheliff, the largest in Algeria which constitutes the common boundaries between Mostaganem, Abdelmalek Ramdane, Ain Boudinar and Sidi Belaatar. The permanent water of this wadi revitalises the lands and the grounds of proximity by its use in agriculture. The study area is served by a system of important access roads. It is composed of national road, railways and agroforestry tracks.

\section{Image processing}

The aim of the study is to assess the land cover and land use changes along the coastline of Mostaganem in the last three decades. To allow us to realise our aim of conducting a spatiotemporal study over a period of 30 years of land use we used the optical data of the American Landsat satellite because it provides satellite images that cover the desired time period (1985-2015). This satellite is characterised by a good temporal and spatial resolution. Images are acquired during the period by the Thematic Mapper (TM) sensor '30m' Enhanced Thematic Mapper (ETM) ' $28.5 \mathrm{~m}$ ' having almost the same spatial resolution $(30 \mathrm{~m})$. To save the computing time and storage space for the optical disk data, we have cut raw satellite images using the ArcGIS10.0 software according to the size of the study area. To format the scenes, we performed a geometric and radiometric correction on the images. For this, we used the techniques of coregistration and radiometric correction of the thumbnails. This technique allowed us to render all the images on the same place (superimposable pixels) and the radiometric values on the same level (usable pixels). To delimit the study area through a GIS, an operation of crossing information layers using the Comgeo digital file available in Shapefile (Shp) format was used.

\section{Classification of units of land use}

This study proves that integration of GIS and remote sensing technologies is an effective tool for urban planning and management (Mallupattu, Reddy, 2013; Duraisamy et al., 2018).To carry out the spatiotemporal study of land use over a 30 -year period, Corine Land Cover (CLC) nomenclature was used by exploit-
Table 2. List of satellite imagery used in this study.

\begin{tabular}{|l|l|l|}
\hline 1985 Period maps & 1995 Period maps & 2015 Period maps \\
\hline 1-1985-01-04.tif & 4-1995-07-27.tif & 9-2010-06-18.tif \\
\hline 2-1987-03-31.tif & 5-1995-08-12.tif & 10-2010-08-05.tif \\
\hline \multirow{3}{*}{$3-1990-11-18 . t i f$} & 6-1997-02-06.tif & 11-2014-07-31.tif \\
\cline { 2 - 3 } & 7-2003-05-22.tif & 12-2014-12-22.tif \\
\cline { 2 - 3 } & 8-2007-05-09.tif & 13-2015-02-08.tif \\
& & 14-2015-08-03.tif \\
\hline
\end{tabular}

ing data from Landsat satellite images with a resolution of $30 \mathrm{~m}$ (Robert, 2016) (Table 2).

The Global Positioning Satellite (GPS) tool was used to locate field samples. To classify the thematic objects present in the area, CLC classification was used. The latter is a standard European typology based on the classification of Corine and Ramsar. It is modified and developed according to the requirement of the Mediterranean basin. It describes the occupancy and land cover units present in the Mediterranean (Beltrame et al., 2014; Weise et al., 2012). The chosen method is based on the segmentation and supervised automatic classification of the processed images focused on a segmentation of the scenes with an average tolerance of 10 , in order to obtain segments or simply forms of thematic objects of average sizes. To assign the shape segments, we used multisource data (management documents, cartography, Google Earth images, studies and field observations).

\section{Results}

Three different satellite images were used to analyse the dynamics of the occupation of the studied space (winter 1985, 1995 and 2015) (Fig. 3).

The analysis identified seven thematic object classes for the study area, which are described and coded as follows :agricultural training (CLC24), forestry formations (CLC31), natural wet meadows (CLC2313), water chart (CLC512), dunes-sands and beaches (CLC331), open space with or without little vegetation (CLC33), artificial milestones or urbanized areas (CLC11).

\section{Spatiotemporal occupation and land cover at different dates}

In the year 1985, the supervised classification enabled us to draw a distribution map of the units of occupation and land cover for

Table 3. Dynamics of land occupation in the study area (in ha).

\begin{tabular}{|l|c|c|c|c|}
\hline Units of occupation and land cover & $\mathbf{1 9 8 5}(\mathbf{h a})$ & $\mathbf{1 9 9 5}(\mathbf{h a})$ & $\mathbf{2 0 1 5}(\mathbf{h a})$ & Gap(ha) \\
\hline Agricultural training & 42356 & 39570 & 38301 & -4055 \\
\hline Forestery formations & 8207 & 9196 & 9298 & 1091 \\
\hline Natural wetmeadows & 794 & 781 & 425 & -369 \\
\hline Water chart & 246 & 264 & 462 & 216 \\
\hline Dunes, sands and beaches & 394 & 237 & 381 & -13 \\
\hline Unproductive land & 900 & 2084 & 1589 & 689 \\
\hline $\begin{array}{l}\text { Artificial milestones } \\
\text { (Urbanised area) }\end{array}$ & 2604 & 3672 & 5049 & 2245 \\
\hline
\end{tabular}



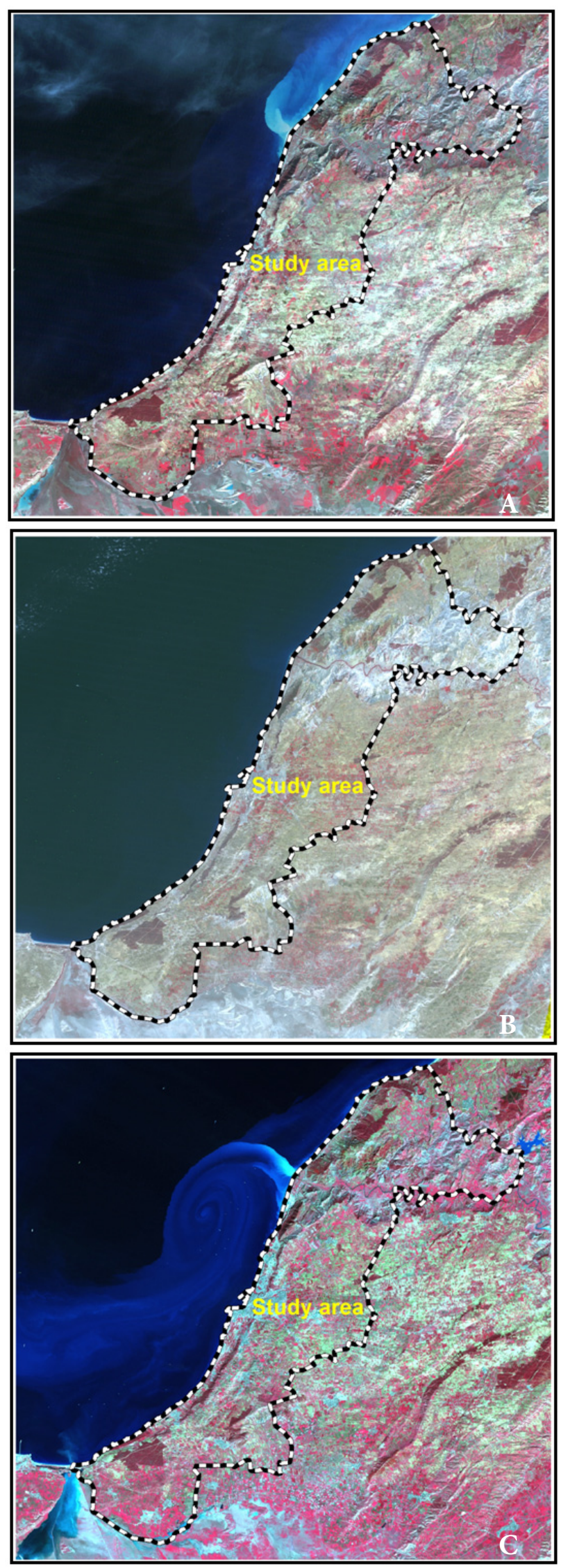

Fig. 3. Landsat TM satellite image extract of study area in three dates. (A:1985 , B:1995 , C:2015) the study area (Fig. 4), where the seven thematic categories were present. Plant formations covered $92 \%$ of the area, urbanisation was only $4.7 \%$ and unoccupied areas covered the remaining $2.3 \%$. In the year 1995 , plant formations covered $88 \%$ of the total area and urbanisation and unexploited land accounted for 6.6 and $4.2 \%$, respectively (Fig. 5). During the period 2015, plant formations covered $85 \%$, urbanisation $9 \%$ and unexploited areas accounted for $3.7 \%$ (Fig. 6).

\section{Analysis of results}

The most urbanisation-threatened natural areas represent $73.5 \%$ of the total area, that is, an average annual loss of more than 146 ha. Spaces that have increased are urban spaces; the unexploited spaces are also destined for urbanisation and have increased by 689 ha or a total of 3134 ha, which represents $5.6 \%$ of the total area. Thus, the average annual growth rate of urban space is of the order of more than 104 ha (Table 3).

\section{Spaces having increased}

It is the urban space that has experienced the greatest increase compared to other spaces, mainly at the expense of agricultural land and coastal landscapes (dunes) (Table 4).

The municipalities with the highest rate of urbanisation are Mostaganem, Kheir Eddine, Sayada, Hassi Maméche and Mezghrane, totalling more than 1823 ha or more than $74 \%$, given their proximity to the coast (Table 4 , Fig. 7 ).

\section{Spaces experiencing regression}

The agricultural areas that occupy the flat lands and areas near the sea have been most heavily urbanised as shown in Table 5 . Natural meadows have also declined and the situation is summarised in Table 6.

\section{Summary of observations}

As shown in Table 7, it is the urban space that is experiencing the greatest growth; this increase has happened to the detriment of the agricultural area which is characterised by sandy-clay soils near the sea that are very popular for market gardening,

\section{Discussion}

Analysis of the spatiotemporal data of the extent of artificialisation shows that the urbanised surfaces since 1985 have experienced extensions. The largest were located at the chief towns of Mostaganem (672 ha), Kheir Eddine (360 ha), Sayada (356 ha), Hassi Maméche (222 ha), Mezghrane (213 ha), Abdelmalek Ramdane (166 ha) and Fornaka (118 ha). The extension of urbanised areas in 30 years has been estimated as $4 \%$ of the total area. The artificial areas were previously occupied by agriculture (3\%) and forest formations (1\%). Elaboration of classification of the different areas covered by the seven land cover categories makes it possible to better understand and analyse the dynamics of land occupation from 1985 to 2015.Statistical analysis of data shows that these areas have undergone a change in their use, since the areas of vegetation formation (agriculture + forestry) 


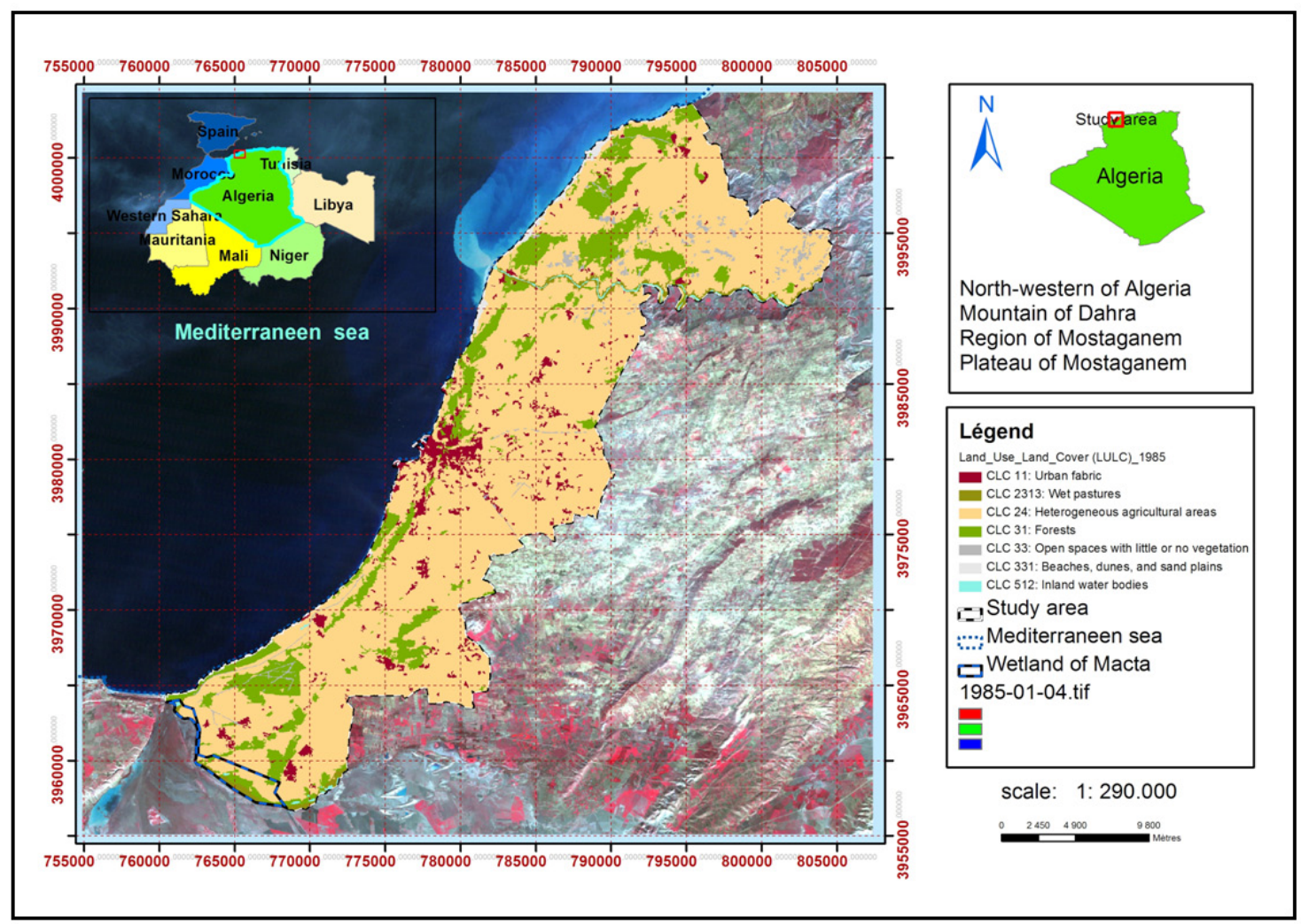

Fig. 4. Map of occupation and land cover (period 1995).

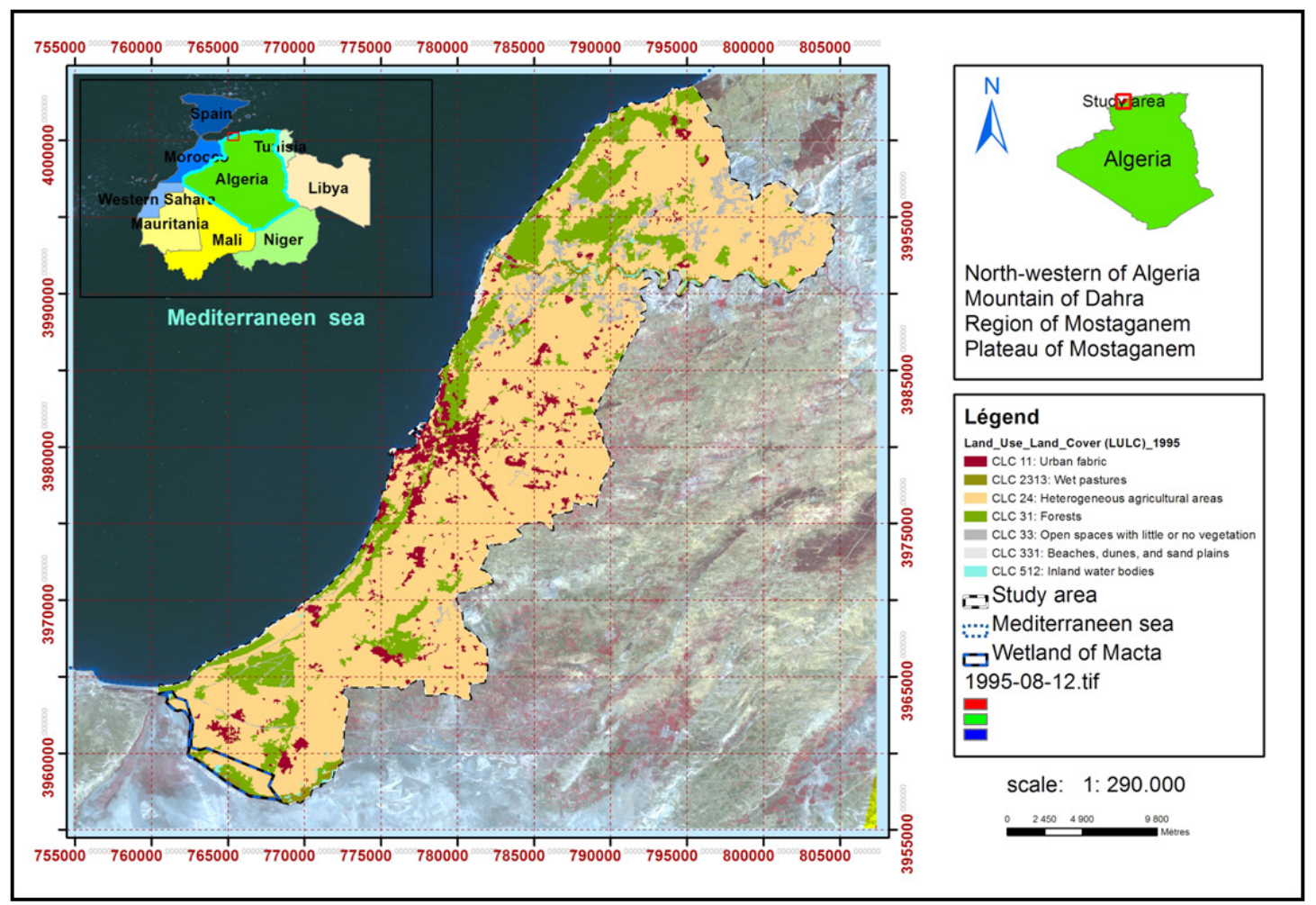

Fig. 5. Map of occupation and land cover (period 1995). 


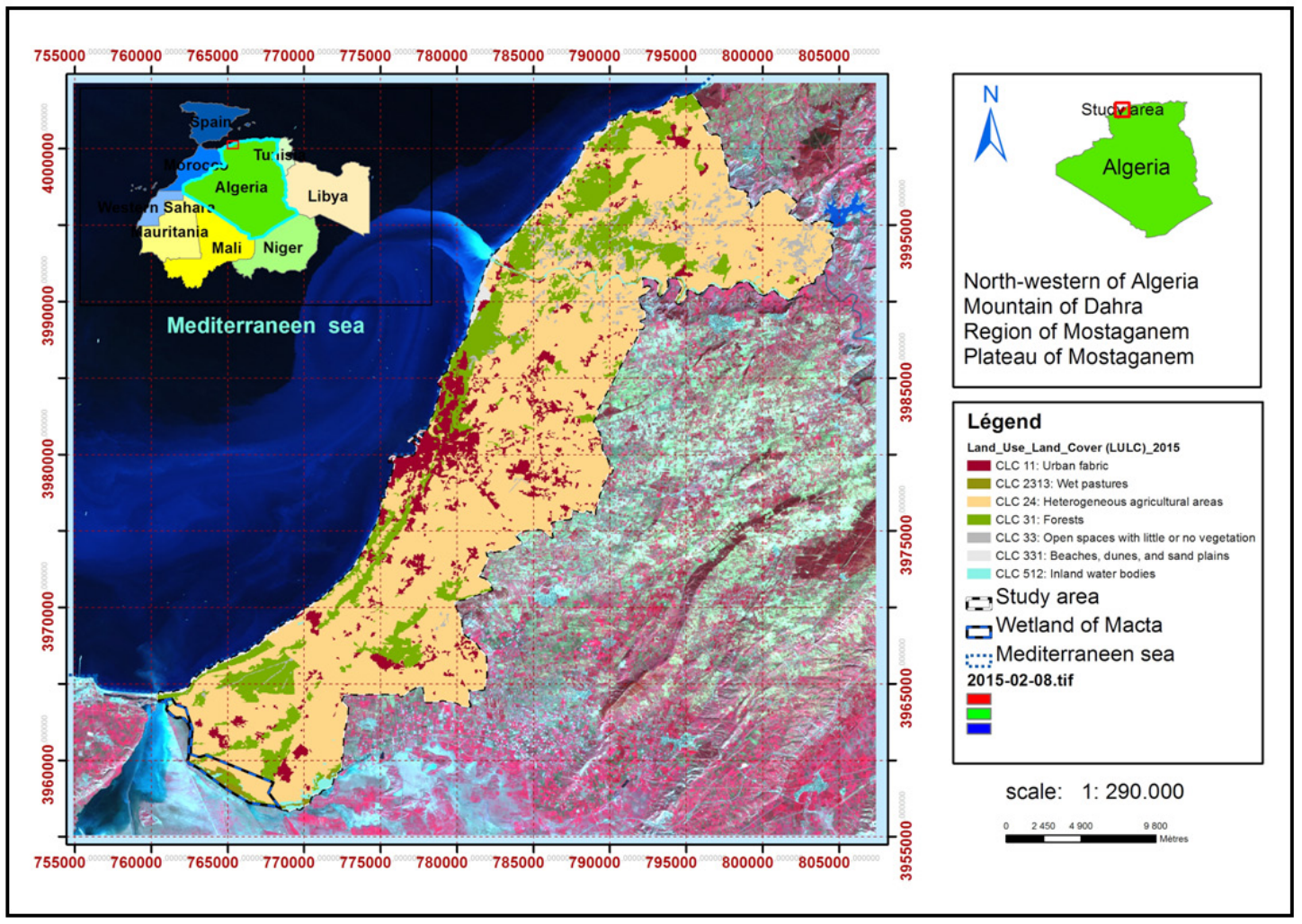

Fig. 6. Map of occupation and land cover (period 2015).

Table 4. Dynamics and evolution of urban space in the study area (in ha).

\begin{tabular}{|l|c|c|c|c|c|}
\hline Municipalities & $\mathbf{1 9 8 5}(\mathbf{h a})$ & $\mathbf{1 9 9 5}(\mathbf{h a})$ & $\mathbf{2 0 1 5}(\mathbf{h a})$ & $\mathbf{1 9 8 5}$ to 2015 gap (ha) & Rate (\%) \\
\hline Mostaganem & 749 & 1008 & 1421 & 672 & 27.5 \\
\hline Kheir Eddine & 324 & 426 & 684 & 360 & 14.72 \\
\hline Sayada & 267 & 449 & 623 & 256 & 9.56 \\
\hline Hassi Mameche & 233 & 294 & 455 & 222 & 8.71 \\
\hline Mezaghrane & 183 & 364 & 396 & 213 & 6.79 \\
\hline Abdelmalek Ramdane & 170 & 217 & 336 & 166 & 4.82 \\
\hline Fornaka & 252 & 361 & 370 & 118 & 4.13 \\
\hline Ain Nouissi & 150 & 202 & 251 & 101 & 3.31 \\
\hline Stidia & 133 & 144 & 214 & 81 & 3.60 \\
\hline Sidi Belattar & 73 & 106 & 161 & 88 & \\
\hline
\end{tabular}

have experienced a loss of 3310 ha, that is, an average annual loss of 110 ha. The urbanised areas initially estimated at 2604 ha in 1985 occupied an area of 5049 ha in 2015, an estimated difference of 2445 ha and an average annual extension of 81.5 ha. The area occupied by water surfaces initially estimated at 246 ha in 1985 covered 462 ha in 2015, an increase of 216 ha induced by the Macta natural reserve or an average annual increase of $7.2 \mathrm{ha}$. The predominantly agricultural region of Mostaganem is turning back under the effect of the urbanisation policy towards a touristic and metropolitan vocation. During the three decades of study, the pressure of urbanisation remains the strongest and is imposed by demographic explosion. Thus, it is the agricultural area which remains the most threatened, while it contains soils of strong agronomic potential mainly for market gardening, vineyards and arboriculture. Global patterns of urbanisation have had significant implications for biodiversity. Habitat conversion driven by urbanisation will be important in the future in coastal systems as well as biomes that are disproportionately urbanised (McDonald et al., 2013). Coastal protection in the Mostaganem region and its great biodiversity (Yahi et al., 2012; Vela et al., 2016) depend on the analysis of land use dynamics. Actions in support of ecosystem services should be considered in planning and management plans (Xu et al., 2016). According to the results obtained, the spatiotemporal difference in total area per land use category gives an indication of the amount of land that is undergoing change from year to year. As mentioned 


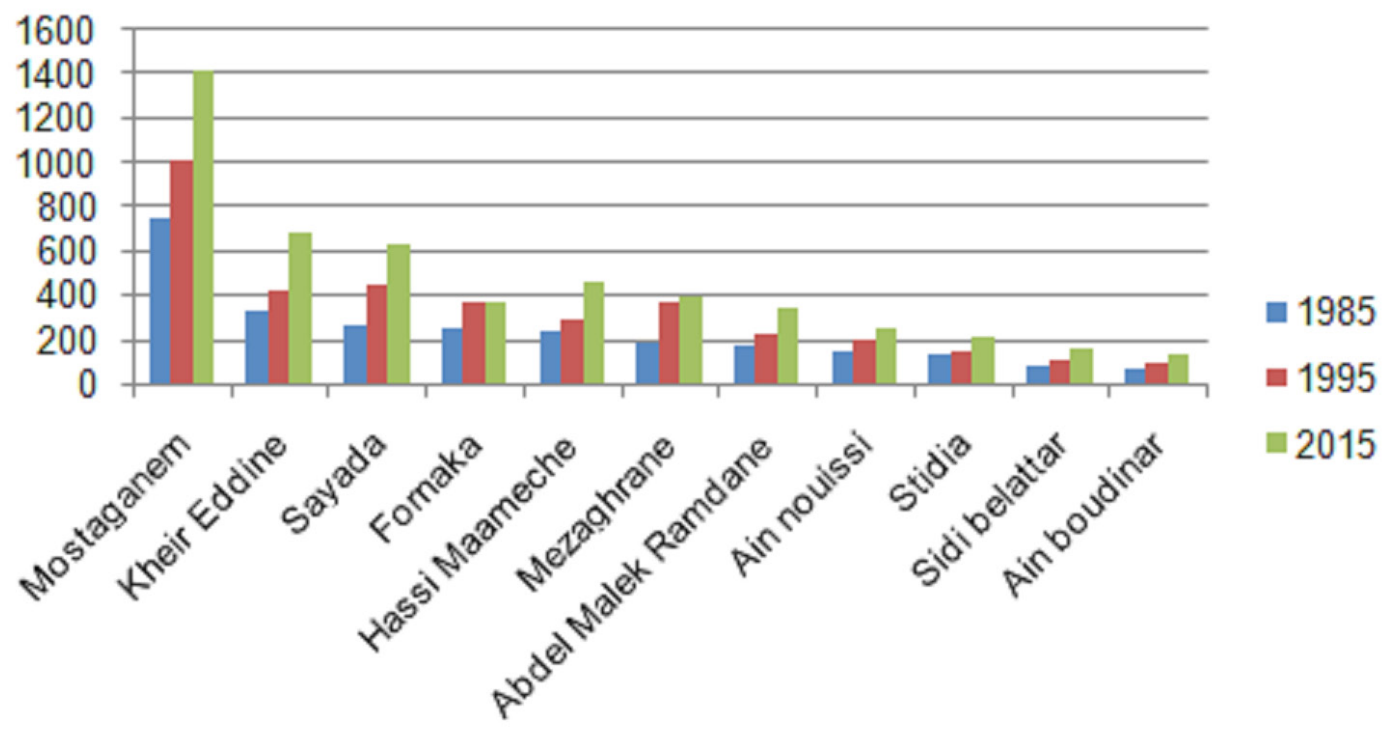

Fig. 7. Urban dynamics during the periods 1985, 1995 and 2015.

Table 5. Dynamics of agricultural space in the eleven municipalities.

\begin{tabular}{|l|c|c|c|c|c|}
\hline Municipalities & $\mathbf{1 9 8 5}(\mathbf{h a})$ & $\mathbf{1 9 9 5}(\mathbf{h a})$ & $\mathbf{2 0 1 5}(\mathbf{h a})$ & $\mathbf{1 9 8 5 - 2 0 1 5}$ Gap (ha) & Rate (\%) \\
\hline Mostagnem & 2306 & 1483 & 1126 & -1180 & -29.12 \\
\hline Kheir Eddine & 4310 & 4207 & 3920 & -390 & -9.62 \\
\hline Sayada & 4042 & 3879 & 3686 & -356 & -8.78 \\
\hline Fornaka & 4676 & 4794 & 4657 & -19 & -0.46 \\
\hline Hassi Mameche & 5281 & 5212 & 4972 & -309 & -7.62 \\
\hline Mezaghrane & 1209 & 1019 & 1009 & -200 & -4.93 \\
\hline Abdelmalek Ramdane & 5242 & 4652 & 4556 & -686 & -16.93 \\
\hline Ain Nouissi & 2571 & 2470 & 2411 & -160 & -3.94 \\
\hline Stidia & 3460 & 3402 & 3376 & -84 & -2.07 \\
\hline Sidi Belattar & 5998 & 5627 & 5520 & -478 & -11.79 \\
\hline Ain Boudinar & 3124 & 2732 & 2935 & -189 & -4.66 \\
\hline
\end{tabular}

Table 6. Dynamics of natural medows (area in ha).

\begin{tabular}{|c|c|c|c|c|c|}
\hline Municipalities & 1985(ha) & 1995(ha) & 2015(ha) & Gap & Rate (\%) \\
\hline Mostaganem & 30 & 46 & 12 & -18 & 4.83 \\
\hline \multicolumn{6}{|l|}{ Kheir Eddine } \\
\hline \multicolumn{6}{|l|}{ Sayada } \\
\hline Fornaka & 286 & 313 & 251 & -53 & 14.24 \\
\hline \multicolumn{6}{|l|}{ Hassi Mameche } \\
\hline \multicolumn{6}{|l|}{ Mezaghrane } \\
\hline Abdelmalek Ramdane & 45 & 36 & 28 & -17 & 4.56 \\
\hline \multicolumn{6}{|l|}{ Ain Nouissi } \\
\hline \multicolumn{6}{|l|}{ Stidia } \\
\hline Sidi Belattar & 286 & 216 & 75 & -211 & 56.72 \\
\hline Ain Boudinar & 109 & 144 & 36 & -73 & 19.62 \\
\hline Total & 756 & 755 & 402 & 372 & \\
\hline
\end{tabular}


Table 7. Evolution of units of land use between 1985 and 2015 in the study area.

\begin{tabular}{|c|c|c|c|c|c|c|c|}
\hline \multirow{2}{*}{ Categories } & \multicolumn{2}{|c|}{ Period 1985} & \multicolumn{2}{|c|}{ Period 1995} & \multicolumn{2}{|c|}{ Period 2015} & \multirow{2}{*}{ Gap } \\
\hline & Surface ha & Rate \% & Surface ha & Rate \% & Surface ha & Rate \% & \\
\hline Plant formations & 51334 & 92 & 49547 & 89 & 48024 & 86.5 & -5.5 \\
\hline Water bodies & 246 & 0.40 & 264 & 0.5 & 462 & 0.8 & 0.4 \\
\hline Unproductive land & 1317 & 2.30 & 2321 & 4 & 1970 & 3.5 & 1.2 \\
\hline Artificial milestones & 2604 & 4.70 & 3672 & 6.6 & 5049 & 9 & 4.3 \\
\hline
\end{tabular}

previously, the estimated quantity and characterisation of change is dependent on spatial scale. It is related to many factors including soil type (Daoudi, Sitayeb, 2020), climate, topography, urbanisation and demographic pressure (Tomlinson et al., 2018; Rabehi et al., 2018, 2019b). Application of satellite imaging methods has resulted in digital map products that are reproducible, consistent and up-to-date. The maps developed are compiled based on geographical and alphanumeric data. Analysis of the results obtained shows that the soils of the zone have undergone a great change in their land use. Agricultural and forest ecosystems have been strongly impacted by the change; it has caused a loss of $5 \%$ of the total area. The converted areas are currently occupied by artificial spaces and unproductive soils which cover $4 \%$ and $1 \%$ of the total study area, respectively. The predominant negative trend in the Land use and land cover classes can also be attributed to the expansion. The primary cause of these losses is the expansion of urban development (Awuh et al., 2018; Elmqvist et al., 2010).

\section{Conclusion}

The overall evolution of the different types of land use is summarised by a regression of the space occupied by plant formations by $5.5 \%$, which is an increase of $1.2 \%$ of the unproductive space and $4.3 \%$ of the artificialised space. The study of the dynamics of land use in the Mostaganem region reveals a trend which is national, showing diversion of agricultural land with high agronomic potential towards urbanisation. This phenomenon has already been underlined by Bendjaballah Boudemagh in 2013, who estimated that in Algeria, 162,000 ha of farmland have been urbanised for more than 50 years. Despite the existence of legislation for protecting it, the coastal area remains the prey of urban planning. During the last 30 years (1985-2015), landscapes of the 11studied municipalities have undergone a change in their assignments and the most impacted municipalities are Mostaganem, Sidi Belaatar, Kheir Eddine, Sayada, Hassi Maméche, Mezghrane, Abdelmalek Ramdane and Fornaka. The impact of the change is translated on the ground by the conversion of surfaces of vegetal formations into artificial and unproductive surfaces. Converted surfaces cover $6 \%$ of the total area of all municipalities. It should be noted that in terms of management and protection of the coast in Algeria, much remains to be done. It turns out that the littoral law encounters serious implementation difficulties (Kacemi, 2011). Even if the forest area shows a slight increase, our results show that the state of degradation is quite advanced since more than $85 \%$ of these ecosystems are degraded low formations (based mainly on bushy species). Application of the principles of sustainable development, whose objectives are to maintain balance between urban development and preservation of agricultural and forest lands, will help in achieving the aim. This leads to the preservation of soils, ecosystems and natural landscapes and safeguarding of the plant heritage (Berezowska-Azzag, 2013). Unfortunately, these elements are not really taken into account despite the existence of legislation; it is the land crisis that prevails. One of our aims is to provide support for the principals strategies and tools belonging to sustainable land cover, land use planning and management by the thematic typology identified in this process. The proximity of the study area to the Mediterranean Sea, its geographical position and its adaptive relief to all occupation units and land covers make it a highly diversified area. The ecological inventory is reflected in the existence of different types of soils, highly diversified forests, plains ,wetlands classified as a Ramsar site such as Macta wetlands and key biodiversity areas (KBAs) Dahra mountains, habitats with plant biodiversity that we must preserve. In the coastal areas, KBAs are mainly threatened by urbanisation, excessive tourism pressure and pollution, fire and overgrazing (Benhouhou et al., 2018; Menoueret al., 2017), as in other cities of Algeria. Reconciliation between economic and social development (Khelil et al., 2019; Boubekri et al., 2018), spatial planning, ecotourism(Bernard et al., 2016) and protection of natural resources are the key to sustainable development of the Algerian coastline.

\section{References}

Aguejdad, A., Houet, T. \& Hubert-Moy L. (2017). Spatial validation of land use change models Using multiple assessment techniques: A case study of transition potential models. Environmental Modeling Assessment, 22, 591-606. DOI: 10.1007/s10666-017-9564-4.

ANAT, National Agency for Spatial Planning (1997). Planner planning and urban planning of Mostaganem.

ANAT, National Agency for Spatial Planning (2006). Revision of the master plan of planning and urban planning of the Mostaganem group SayadaMazagran.

Awuh, M.E., Officha, M.A., Okolie, A.O. \& EneteI C. (2018). Land-use/landcover dynamics in Calabar metropolis using a combined approach of remote sensing and GIS. Journal of Geographic Information System, 10(4), 398-414. DOI: 10.4236/jgis.2018.104021.

Beltrame, C., Guelmami, A. \& Perennou C. (2015). Trends in land cover change in coastal wetland around the mediterranean basin. Survey findings from 1975 to 2005. Journal of Mediterranean Geography, 125, 97-111. DOI: $10.4000 /$ mediterranee.8046.

Bendjaballah Boudemagh, O. (2013). Urban policies, agriculture and land market: What future for periurban agriculture in Constantine? Algeria. Cahier Agricole, 22(6), 544-551. DOI: 10.1684/ag.0670.

Benhouhou, S., Yahi, N. \& Vela E. (2018). Key Biodiversity Areas (KBAs) for plants in the Mediterranean region. Chp 3 Algérie. In M. Valderrabano, T. Gil, V. Heywood \& B. De Montmollin (Eds.), Conserving wild plants in the south and east Mediterranean region (p. 161). Gland, Málaga: IUCN. DOI: 10.2305/IUCN.CH.2018.21.en.

Berezowska-Azzag, E. (2013). Intelligence urbaine au-delà d'une planification. Courrier du Savoir, 16, 55-63. http://revues.univ-biskra.dz/index.php/cds/ article/view/387 
Bernard, S., Roche, Y. \& Sarrasin B. (2016). Écotourisme, aires protégées et expansion agricole: Quelle place pour les systèmes socio-écologiques locaux? Canadian Journal of Development Studies, 37(4), 422-445. DOI: 10.1080/02 255189.2016.1202813.

Boubekri, I., Caveen, A., Djebar, A., Amara, R. \& Mazurek H. (2018). Structure and spatio-temporal dynamics of the artisanal small-scale fisheries at the future MPA of "Taza” (Algerian coast, SW Mediterranean). Mediterranean Marine Science, 19(3), 555-571. DOI: 10.12681/mms.16192.

Boudjenouia, A., Fleury, A. \& Tacherift A. (2008). Suburban agriculture in Setif (Algeria): Which future in face of urban growth? Biotechnologie, Agronomie, Société et Environnement, 12(1), 23-30. http://popups.ulg.ac.be/1780-4507/ index.php?id=2128.

Daoudi, K. \& Sitayeb T.(2020). Effects of land use changes on the soil physicochemical properties in south-western Algeria. Ekológia (Bratislava), 39(3), 224-235. DOI: 10.2478/eko-2020-0017.

Dirassat (2008). Schéma directeur d'aménagement de l'aire métropolitaine d'Oran. Studyoffice mission report.

Duraisamy, V., Bendapudi, R. \& Jadhav A. (2018). Identifying hotspots in land use land cover change and the drivers in a semi-aridregion of India. Environ. Monit.Assess., 190(9), 535. DOI: 10.1007/s10661- 018-6919-5.

Elmqvist, T., Fragkias, M.J., Goodness, J., Güneralp, B.P., Marcotullio, J., McDonald, R.I., Parnell, S., Schewenius, M., Sendstad, M. \& Wilkinson C. (Eds.) (2013). Urbanization, biodiversity and ecosystem services: Challenges and opportunities. A global assessment. Netherlands: Springer. DOI: 10.1007/97894-007-7088-1.

Ghodbani, T. \& Berrahi-Midoun F. (2013). Littoralization in western Algeria: Multiscalar approaches to interactions men areas-ecosystem. Space Populations Societies, 1-2, 231-243. http://journals.openedition.org/eps/5488

Ghodbani, T., Kansab, O. \& Kouti A.(2016). Development of tourism in Algeria facing the issue of coastal areas protection. The Mostaganem coast case study. Etudes Caribéennes, 33-34. DOI: 10.4000/etudes caribeennes.9305.

Ghodbani, T., Milewski, A. \& Bellal S. (2015). The wetlands of the Terga area, vulnerable coastalecosystem in the southern Mediterranean (western Algeria). Méditerranée, 125, 153-164. DOI: 10.4000/mediterranee.8104.

Ghodbani, T. \& Semmoud B. (2010). Coastal urbanization in Algeria, processes and environment impacts: The case of the bay Aïn el Turck. Etudes Caribée nnes, 4431. http://journals.openedition.org/étudescaribéennes/4431.

Gounaridis, D., Apostolou, A. \& Koukoulas S. (2016). Land cover of Greece, 2010: a semi-automatedclassification using random Forests. Journal of Maps, 12(5), 1055-1062. DOI: 10.1080/17445647.2015.1123656.

Güngöroğlu, C., Kavgac, A., Coşgun, U., Çalıkoğlu, M., Örtel, E. \& Balpınar N. (2017). Applicability of European landscape typology in Turkey (Çakırlar Watershed case/Antalya). Landscape Research, 43(6), 831-845. DOI 10.1080/01426397.2017.1386776.

Hasse, J.E. \& Lathrop R.G. (2003). Land resource impact indicators of urban sprawl. Applied Geography, 23, 159-175.DOI: 10.1016/j.apgeog.2003.08.002.

Houet, T., Verburg, P.H. \&Loveland T.R. (2010). Monitoring and modeling landscape dynamics. Landsc. Ecol., 25, 163-167. DOI: 10.1007/s10980-0099417-x.

Journal Officiel de la République Algérienne (2002). Lois n 02-02 du 5 février 2002 relative à la protection et à la valorisation du littoral (pp.18-22).

Kacemi, M. (2011). Protection and development of the coastal areas in Algeria: Legislation and instruments. The case of Oran's coastal areas. Etudes Caribéennes, 20, 5959. DOI: 10.4000/etudescaribeennes.5959.

Khelil, N., Larid, M., Grimes, S., Le Berre, I. \&Peuziat I. (2019).Challenges and opportunities in Promoting integrated coastal zone management in Algeria: Demonstration from the Algiers coast. Ocean and Coastal Management, 168, 185-196. DOI: 10.1016/j.ocecoaman.2018.11.001.

Lagabrielle, E., Metzger, P., Martignac, C., Lortic, B. \& Durieux L. (2007). Land use trends on ReunionIsland (1989-2002). M@ppemonde, 86. http://mappemonde.mgm.fr/num14/ articles/art 07205.

Lestrelin, G., Augusseau, X., David, D., Bourgoin, J., Lagabrielle, E. \& Lo Seen D. (2017).Collaborative landscape research in reunion sland: Using spatial modelling and simulation to support territorial foresight and urban planning. Applied Geography, 78, 66-77. DOI: 10.1016/j.apgeog.11.003.

Li, Y., Zhang, X., Zhao, X., Cao, S.M. \& Cao H. (2016). Assessing spatial vulnerability from rapid urbanization to inform coastal urban regional planning. Ocean and Coastal Management, 123, 53-65. DOI: 10.16/J.ocecoaman.2016. 01.010 .

Mallupattu, K.P. \& Reddy J.S. (2013). Analysis of land use/land cover changes using remote sensingdata and GIS at an urban area, Tirupati, India. The Sci- entific World Journal, ID 268623. DOI: 10.1155/2013/268623.

McDonald, R., Marcotullio, P.J. \& Güneralp B. (2013).Urbanization and global trends in biodiversity and ecosystem services. In T. Elmqvist, M.J. Fragkias, J. Goodness, B.P. Güneralp, J. Marcotullio, R.I. McDonald, S. Parnell, M. Schewenius, M. Sendstad,M. \& C. Wilkinson (Eds.), Urbanization, biodiversity and ecosystem services: challenges and opportunities. A global assessment (pp. 31-52). Netherlands: Springer. DOI: 10.1007/978-94-007-708813 .

Menouer, O., Sahah Zerouala, M. \& Dahmen A. (2017). The « Fahs »:A challenge for coastal tourism requalification in Algiers? Etudes Caribéennes, 36. DOI: 10.4000/etudescaribeennes.10829.

Otmani, H., Belkessa, R., Rabehi, W., Guerfi, M. \& Boukhdiche W. (2019). Dégradation des dunes côtières algéroises entre pression de l'urbanisation et conséquences sur lévolution de la ligne de rivage. Geo-Eco-Marina, 25, 131-145. DOI: $10.5281 /$ zenodo.3609777.

Paegelow, M., Camacho Olmedo, M.T., Mas, J.F. \& Houet T. (2014). Benchmarking of LUCC modelling tools by various validation techniques and error analysis. Cybergeo, 701. DOI: 10.4000/cybergeo.26610.

Patra, S. \& Shukla J. (2017). Assessment on physical and anthropogenicactivities and its impact on coastal sand dunes, West Bengal. Journal of Geography, Environment and Earth Science International, 11(3), 1-8. DOI: 10.9734/ JGEESI/2017/35657.

Piano, E., De Wolf, K., Bona, F., Bonte, D., Bowler, D.E., Isaia, M., Lens, L., Merckx, T., Mertens, D., Van Kerckvoorde, M., De Meester, L. \& Hendrickx F (2017). Urbanization drives community shifts towards thermophilic and dispersive species at local and landscape scales. Glob.Change Biol., 23, 25542564.DOI: $10.1111 / \mathrm{gcb} .13606$

Qiang, Y. \& Lam S.N. (2015). Modeling land use and land cover changes in a vulnerable Coastal region using artificial neural networks and cellular automata. Environment Monitoring and Assessment, 187, 57. DOI: 10.1007/ s10661-015-4298-8.

Rabehi,W., Guerfi, M. \& Mahi H. (2018). Mapping the vulnerability of the Bay of Algiers a socio-economic and physical approach to understanding the coast Méditerranée, 19. http://journals.openedition.org/mediterranee/8625.

Rabehi,W., Guerfi, M. \& Mahi H. (2019a). La baie d’Alger, un espace côtier prisé, entre pressions d'urbanisation et gouvernance territoriale. Geo-Eco-Marina 25, 113-130. DOI: 10.5281/zenodo.3609744.

Rabehi, W., Guerfi, M., Mahi, H. \& Rojas-Garcia E. (2019b). Spatiotemporal monitoring of Coastal urbanization dynamics: Case study of Algiers' Bay, Algeria. Journal of the Indian Society of Remote Sensing, 47, 1917-1936. DOI 10.1007/s12524-019-01037.

Robert, S. (2016). Between urban sprawl and densification: An accurate approach of coastal urbanization in Provence. Cybergeo, 764. DOI: 10.4000/ cybergeo.27451.

Semmoud, B. \& Ladhem A. (2015). Periurban agriculture faced with agrarian vulnerabilities in Algeria. Territoire en Mouvement, Revue de Géographie et Aménagement, 25-26. DOI: 10.4000/tem.2845.

Sharma, R., Nehren, U., Rahman, S.A., Meyer, M., Rimal, B., Seta, G. \& Bara H.(2018). Modeling land use and land cover changes and their effects on biodiversity in central Kalimantan, Indonesia. Land, 7, 57. DOI: 10.3390/ land 7020057.

Tomlinson, U., Dragosits, P., Levy, E., Thomson, A.M. \& Moxley J. (2018). Quantifying gross vs. net agricultural land use change in Great Britain using the integrated administration and control system. Sci. Total Environ., 628-629, 1234-1248. DOI: 10.1016/j.scitotenv.2018.02.067.

Vela, E. (2017). From the biodiversity inventory to conservation priorities in the Mediterranean basin hotspot: can wefill knowledge gaps? Thesis presented for the diploma of accreditation to direct research, University of Montpellier, France.

Weise, K., Wolf, B., Fitoka, E., Van Valkengoed, E., Bonino, E., Hansen, H. \& Paganini M. (2012). Glob wetland II. A regional pilot project of the Ramsar convention on wetlands. Symposium Panel ESRIN. Frascati, Italy, 23-27 Feb. 2012.

Xu, Q.R., Yang, Y.X., Dong, Y.X., Liu, L. \& Run Q. (2016). The influence of rapid urbanization and land use changes on terrestrial carbon sources/sinks in Guangzhou, China. Ecological Indicators, 70, 304-316.DOI: 10.1016/j.ecolind.2016.05.052.

Yahi, N., Vela, E., Benhouhou, S., De Belair, G. \& Gharzouli, R. (2012). Identifying important plants areas (Key biodiversity areas for plants) in northern Algeria. Journal of Threatened Taxa, 4(8), 2753-2765. DOI: 10.11609/JoTT. o2998.2753-65. 